\title{
JEALOUSY IN OTHELLO
}

Sanja Merzić ${ }^{1}$

Faculty of Education, Mostar

Received: 10.05.2011

Accepted: 01.10.2011
Original scientific pape

UDC: 821.111.09-2 Shakespeare W.

159.942.6:82

\begin{abstract}
The intent of this paper is to address the theme of jealousy in Shakespeare's tragedy Othello, the Moor of Venice (Othello) through various characters, especially focusing on characters of Othello and Iago. Also, this paper will show how an emotion strong as jealousy can destroy not only its carrier but everyone that surrounds him/her if used without control.
\end{abstract}

Key words:jealousy, types of jealousy, Othello, Iago, Desdemona, Cassio, green-eyed monster

\section{INTRODUCTION}

One of the most common and intense emotions that a human being can experience is certainly jealousy. A feeling that starts to appear in our early age (some research claim that even 6 month old infants feel jealousy) and keeps growing as we get older is an often theme of many scientific works, whether they are from the field of psychology, sociology or even biology. And not only these. Artists have explored the theme of jealousy in movies, paintings, plays, poems, songs and books-more on this will be said later.

The word jealousy comes from:the French jalousie, formed from jaloux (jealous), and further from Low Latin zelosus (full of zeal), in turn

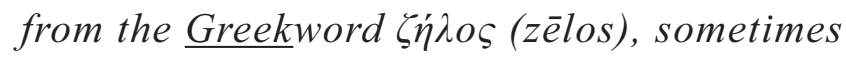

"jealousy", but more often in a positive sense "emulation, ardour, zeal" (with a root connoting "to boil,ferment"; or "yeast")(http://en.wikipedia. org/wiki/Jealousy).

It is defined as: ... a secondary emotion and typically refers to negative thoughts and feeling of insecurity, fear and anxiety over an anticipated loss of something that a person values, particularly in reference to a human connection (http:// en.wikipedia.org/wiki/Jealousy). It consists of many (negative) emotions: anger, disgust, resentment and fear.

1 Correspodence to:

Sanja Merzić, Faculty of Education, Mostar

XXII ul. 95., 88 104, Mostar, B\&H

Phone: +387 62265018

E-mail: me_sanjaahoo.co.uk 
There are many types of jealousy human body can experience. I will name only those which are important for this work: romantic, workplace, family, power and sexual jealousy. Emphasis is put on workplace and sexual jealousy.

As I have mentioned previously many artists or to be more exact writers have written on this topic.

Some have dealt with jealousy in relationships and among children of the same parents, while others wrote about workplace and power related jealousy. Among those writers is William Shakespeare, the best playwriter literature has granted us with.

Shakespeare in his tragedy Othello, the Moore of Venice combines all of the above mentioned types of jealousy. Why? I will try to give an answer in this paper.

So, shall we start? Othello (around 1603) revolves around four main characters: Othello, a general in the Venetian army, his ensign Iago, his lieutenant Cassio and Desdemona, his wife. All these characters have their virtues and flaws, but if we shall speak about flaws and jealousy as a part of them, Iago certainly stands out. Iago is the actuator of the plot; nothing that has to do with jealousy and the play itself happens without Iago's intervention. That we already seein Act I, Scene I. Here we have first hint of jealousy.

Desdemona, daughter of a Venetian senator marries Othello without her father's knowledge. Iago, jealous and already filled with hatred towards Othello:

\section{Roderigo: Thou told'st me thou didst hold}

him in thy hate.

Iago: Despise me if I do not.

(www.bartleby.com/70/4411.html)

because he gave the position of a lieutenant to Cassio,finds in this all the necessities he needed to start his cruel revenge to Othello.
The first step in his jealousy filled plan is to turn Desdemona's father (Brabantio) against Othello. To do so, he will need help of Roderigo (Desdemona's ex-fiancé). He persuades Roderigo to tell Desdemona's father she has married the Moor. Roderigo does so, and Iago accomplishes his goal. In anger Brabantio says to Othello one of the key sentences of the play which will later have a huge impact on the way Othello conceives Desdemona's fidelity:

Look to her, Moor, if thou hast eyes to see:

She has deceiv'd her father, and may thee.

( www.bartleby.com/70/4413.html)

Although Othello in this moment doesn't believe in the awful slender, the shadow on his wife's chastity has been casted away.

As the play continues Iago reveals another reason of his jealousy towards Othello. He suspects, although he doesn't have a single evidence, that Othello has slept with his wife (Emilia) and therefore he has to ,pay“. In Iago's mind „debt“ will be paid if he sleeps with Desdemona or makes Othello so jealous that he won't be able to think clearly:

... wife for wife;

Or failing so, yet that I put the Moor

At least in jealousy so strong

That judgment cannot cure (www. bartleby.com/70/4421.html).

As he is not able to accomplish the first intention he decides to make Othello mad with jealousy and the right person in doing so is Cassio whom Iago considers not only an abator of his work position but as well of his marriage role.

Like the wind before the storm Iago will circle around Othello giving him pieces of a puzzle which will lead to a false truth in Othello's head: 
Desdemona is unfaithful. Cassio is her lover. They are your enemies and I am your friend. I am the one whom you should have named your lieutenant. Writing about the personality of Iago, Haim Omer and Marcello de Verona (1991, pp.1-12) have said: „(Iago) uses suspicion, hints, affirms by denying, cover his traces, forestalls criticism, and blurs the contours of reality“. Jealousy has destroyed the character of Iago. He has become a shadow of a human being which lurks in the background for his next victim.

And the victim that had to payone of biggest tolls was Othello. Deceived by Iago's honesty mask, Othello destroys not only his reputation and friendship, but the most important thing in his life-marriage with Desdemona. His jealousy is in such proportions that it overcomes Iago'sif having in mind that Iago stays alive and Othello kills his wife and himself. Maybe, or batter said certainly Othello deserved what happened to him-his disbelief in the love of a woman he married couldn't have produced any other consequence.

I cannot find any reason why Othello should be spared of his terrible end. Probably, he thought the same, and that's why he took his life.

Othello picked the fruits of his work,but what is with the other characters(Desdemona, Cassio, Emilia, Bianca)?! It seems they were left with the hardest burden-to carry a Guilt that is not theirs. But that is another story for which I don't have either space or time.

What a better way to finish this paper than with a message of a man who lived jealousy in every breath he took and who felt all its consequences: O! beware, my lord, of jealousy It is the green-ey'd monster which doth mock The meat it feeds on;

(www.bartleby.com/70/4433.html)

\section{CONCLUSION}

Jealousy is a powerful and strong emotion. It can tear down simple things, things not so relevant, but, as well, it can destroy entire systems such as friendships and families. Shakespeare has portrayed ruin of the last two in Othello.

Jealousy of one man has brought misery and unhappiness to many: some lost their friends while others lost much more, as I have shown in this paper. Message that Shakespeare sends and which I try to follow is be aware of the green-eyed monster, which, even if it looks tempting, from time to time, lives nothing unharmed.

\section{REFERENCES}

- Craig, W.J. ed. "[Play/Poem Title]” (2000). The Complete Works of William Shakespeare. London: Oxford University Press: 1914; Bartleby.com.

- Haim, Omer and Verona, de Marcello (1991): Doctor Iago's Treatment of Othello, American Journal of Psychology 45.

- http://en.wikipedia.org/wiki/Jealousy

- http://www.bartleby.com

- Khan, Shahab Yar (2008): O Šekspirovim tragedijama [About Shakespearian tragedies], Sarajevo, B\&H: Dobra knjiga.

- Shakespeare, W. (2006): Tragedije [Tragedies], Zagreb, Croatia: Matica hrvatska. 